\title{
Mineralogy of xenoliths of garnet pyroxenites from kimberlite pipes of Siberian Platform
}

Kuligin, S.S., and Pokhilenko, N.P.

Institute of Mineralogy and Petrography, 630090,Novosibirsk, Russia.

The present work is devoted to the study of the complex of mantle xenoliths of pyroxenite paragenesis from Udachnaya, Mir and Obnazhennaya kimberlite pipes. In general, above 100 nodules of pyroxenites are studied and their complex mineralogo-petrographic exploration is performed.

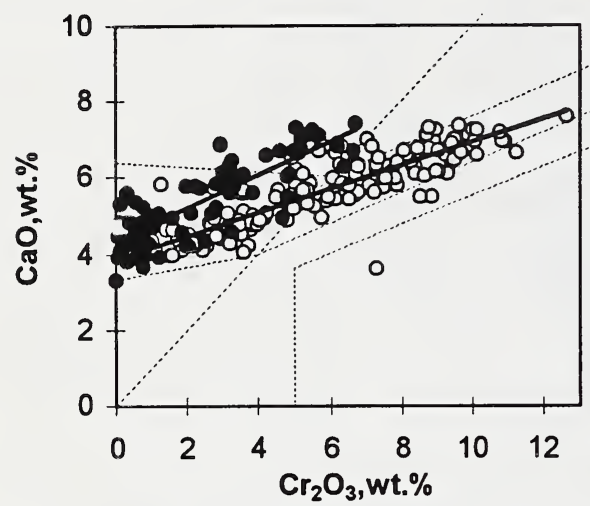

o lherzolites pyroxenites

Fig. 1. $\mathrm{Cr}_{2} \mathrm{O}_{3}$ and $\mathrm{CaO}$ ratio in garnets from xenoliths pyroxenites and lherzolites. Udachnaya pipe.
About $70 \%$ of studied sampling are represented by garnet-bearing varieties.

The detailed petrographic description of the studied rock group was presented earlier in a number of works (Serenko, Kharkiv, 1974; Ukhanov et al., 1988; Kuligin, 1997), therefore, we'll take a close look only at the main peculiarities of the basic rockforming . minerals of pyroxenites and their comparative analysis with the corresponding minerals from the rocks of lherzolite and eclogite composition. In terms of mineralogy of lherzolites and eclogites, both literature data (Ukhanov et al., 1988; Spetsius, Serenko, 1990; Solov'eva et al., 1994) and a great number of our new materials were used.

GARNET. The exact positive correlation between $\mathrm{Cr}_{2} \mathrm{O}_{3}$ and $\mathrm{CaO}$ (Sobolev, 1974) was established for the garnets from lherzolites of xenoliths. The similar tendency is also available for the garnets from the xenoliths of pyroxenite rocks, and more significant dependence between $\mathrm{CaO}$ and $\mathrm{Cr}_{2} \mathrm{O}_{3}$ is

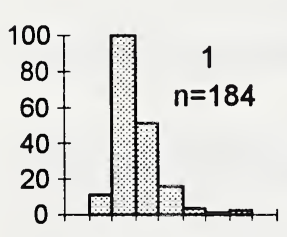

$14 \quad 18 \quad 22 \quad 26$

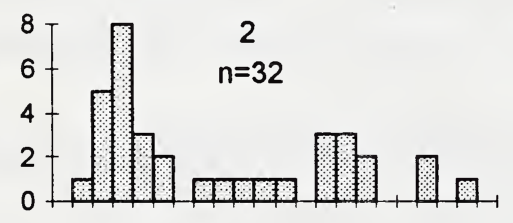

$\begin{array}{lllllll}14 & 20 & 26 & 32 & 38 & 44 & 50\end{array}$

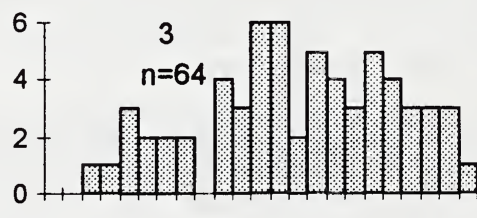

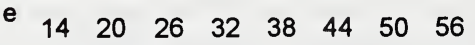

Fig. 2. Ferruginosity distributions of garnets from xenoliths lherzolites (1), pyroxenites (2) and eclogites (3). Udachnaya pipe. $\mathrm{X}-\mathrm{Fe}^{+2} /\left(\mathrm{Fe}^{+2}+\mathrm{Mg}\right)$ in $\%$, Y-quantity.

observed (Fig. 1).

The histograms, illustrating the distribution of ferruginosity of garnets from different rock types are shown in Figure 2. According to this characteristic, the garnets from pyroxenite xenoliths take up the intermediate position between garnets from lherzolites and eclogites. In this case, the comparison of ferruginosity distributions in garnets from different types of xenoliths from Udachnaya pipe is the most demonstrative. Thus, the part of garnets with ferruginosity of above $25 \%$ is $2-3 \%$ in lherzolites, about $50 \%$ - in pyroxenites and about $88 \%$ in eclogites (Fig. 2). 


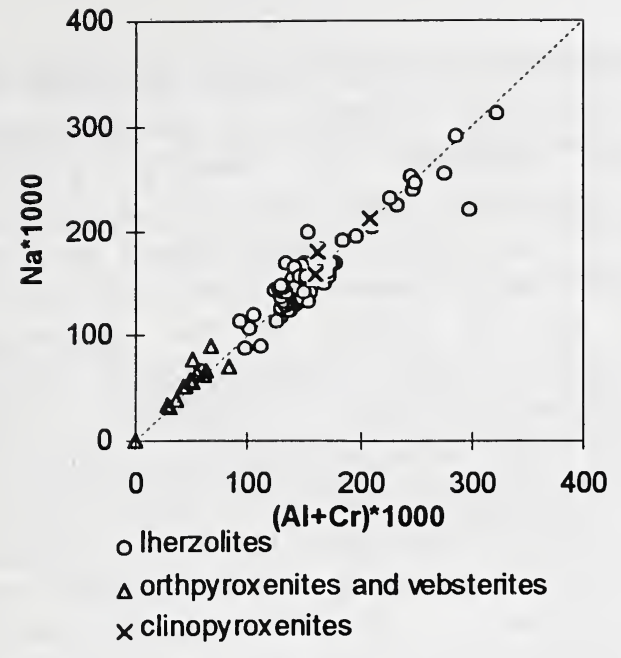

Fig. 3. $\mathrm{Na}$ and $\mathrm{Al}+\mathrm{Cr}$ ratio in clinopyroxenes from xenoliths pyroxenites and lherzolites. Mir pipe.

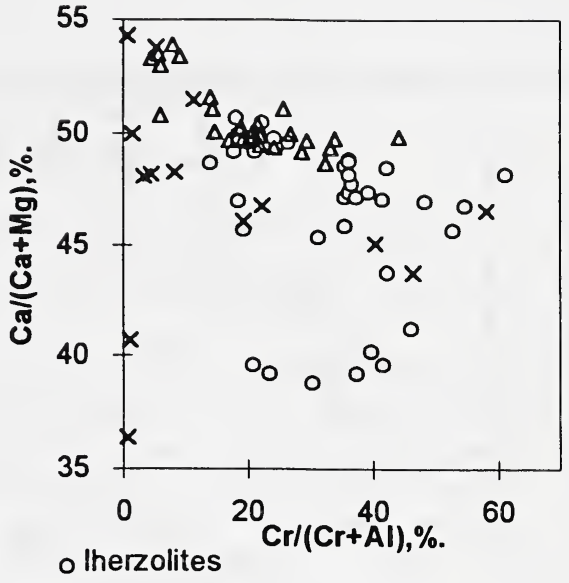

$\Delta$ orthopyroxenites and vebsterites

$x$ clinopyroxenites

Fig. 4. $\mathrm{Ca} /(\mathrm{Ca}+\mathrm{Mg})$ and $\mathrm{Cr} /(\mathrm{Cr}+\mathrm{Al})$ ratio in clinopyroxenes from xenoliths pyroxenites, and lherzolites. Udachnaya pipe.

The similar ferruginosity distribution is also peculiar for the garnets from xenoliths of various types from Mir and Obnazhennaya kimberlite pipes.

CLINOPYROXENE. Generally, the composition of clinopyroxenes is mostly individual for each of the studied kimberlite bodies. It should be noted that there is no excess of $\mathrm{Cr}+\mathrm{Al}$ above $\mathrm{Na}$ in clinopyroxenes from Mir xenoliths, which indicates that $\mathrm{Al}$ content is bound in jadeite molecule, and the Ca-Tchermak-component is practically absent (Fig.3). On the contrary, the significant excess of $\mathrm{Cr}+\mathrm{Al}$ above $\mathrm{Na}$ in clinopyroxenes from a particular part of piroxenites and lherzolites from Udachnaya and Obnazhennaya kimberlite pipes is an indicator of detectable amounts of $\mathrm{Al}^{1 \mathrm{~V}}$. Besides, in Udachnaya and Obnazhennaya kimberlite pipes the field of compositions of clinopyroxenes from pyroxenites limits the field of compositions of clinopyroxenes from lherzolites in the area of high values of $\mathrm{Ca} /(\mathrm{Ca}+\mathrm{Mg})$ (orthopyroxenites and vebsterites) and in the area of low values of $\mathrm{Cr} /(\mathrm{Cr}+\mathrm{Al})$ (clinopyroxenites) (Fig.4). In this case the value of $\mathrm{Cr} /(\mathrm{Cr}+\mathrm{Al})$ ratio in clinopyroxenes from Udachnaya lherzolites is, as a rule, not less than $15-20 \%$. As for Obnazhennaya pipe, this limit is about $9-10 \% \mathrm{Cr} /(\mathrm{Cr}+\mathrm{Al})$. On the contrary, the field of clinopyroxenes from Mir lherzolites completely overlaps the compositions of clinopyroxenes from pyroxenites. The absence of high-chromous varieties is a further peculiarity of clinopyroxenes from Obnazhennaya xenoliths. Thus, if in Mir and Udachnaya kimberlite pipes the value of $\mathrm{Cr} /(\mathrm{Cr}+\mathrm{Al})$ ratio in clinopyroxenes may reach $50-60 \%$ (Fig.4), the same value for xenoliths from Obnazhennaya pipe does not exceed $33 \%$ for lherzolites and 22.3 for pyroxenites.

In clinopyroxene from two xenoliths of garnet clinopyroxenites from Udachnaya pipe a detectable admixture of $\mathrm{K}_{2} \mathrm{O}(0.3$ and $0.5 \mathrm{wt} . \%)$ is marked. According to experimental data such rocks could be formed only at super-high pressures (not less than 50 kbar.).

According to our data, the minerals from garnet clinopyroxenites significantly differ in composition from the corresponding minerals of the rocks of eclogite paragenesis (Kuligin, 1977). Unlike to clinopyroxenes from garnet eclogites, clinopyroxenes from garnet clinopyroxenites do not fall within the field of compositions of omphacite. Ferruginosity of garnet and pyroxene from pyroxenites is, as a rule, significantly lower, than ferruginosity of the corresponding eclogite minerals (fig.5). Unlike to the minerals from eclogites, the minerals from clinopyroxenites have a significant admixture of chromium, reaching 6.5-7wt. $\% \mathrm{Cr}_{2} \mathrm{O}_{3}$ in garnets and it is usually less than $0.25-0.4$ (Kuligin, 1977). 


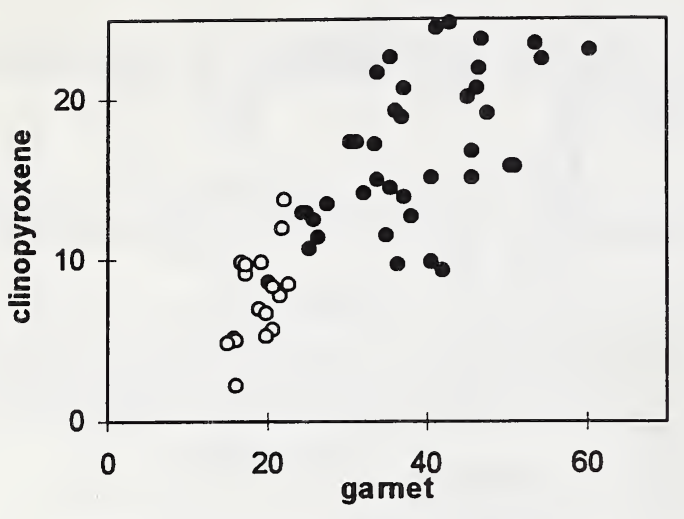

- eclogites o clinopyrox enites

Figure 5. Ferruginosity ratio (in \%) of garnet and coexisting clinopyroxene from xenoliths clinopyroxenites and eclogites.

ORTHOPYROXENE. Though the rages of compositional variations of orthopyroxenes from lherzolites are somewhat greater, orthopyroxenes from pyroxenites are closely related to orthopyroxenes from granular pyrope and spinel-pyrope lherzolites in $\mathrm{Al}, \mathrm{Cr}$, $\mathrm{Na}$ and $\mathrm{Ca}$ content. As for Udachnaya kimberlite pipe, orthopyroxenes from magnesian-ferriferous vebsterites are exceptional. Having the variations of $\mathrm{Al}_{2} \mathrm{O}_{3}$ (1.42.4 wt.\%), $\mathrm{Cr}_{2} \mathrm{O}_{3}(0.1-0.4$ wt.\%) and $\mathrm{CaO}(0.1-$ 0.3 wt.\%) contents close to those of lherzolites, orthopyroxenes of this variety are much more ferruginous

$\left(\mathrm{Fe}^{+2} /\left(\mathrm{Fe}^{+2}+\mathrm{Mg}\right)=15-24.4 \%\right)$ (Kuligin, 1997). Orthopyroxenes with such high ferruginosity are not found in any of the varieties of garnet peridotites.

In Mir and Obnazhennaya kimberlite pipes there are no significant differences in the compositions of orthopyroxenes from lherzolites or pyroxenites.

The peculiarities of mineral composition and P-T parameters of equilibrium of xenoliths pyroxenites allow us to make a conclusion that pyroxenites are present in vertical section of lithospheric part of the Upper Mantle of central parts of Yakutian kimberlite province (Malo-Botuobinsky and DaldynAlakitsky regions) from the crust-mantle boundary $(50 \mathrm{~km})$ up to the depth of about $250 \mathrm{~km}$, this fact indicates the deep-seated character of their parental melt.

\section{References}

Kuligin, S.S., 1997, Complex of xenoliths pyroxenites from kimberlites of different parts of Siberian Platform. Thesis, Novosibirsk, 22 p.

Serenko, V.P., and Kharkiv, A.D., 1974, Petrography and mineralogy of xenoliths pyroxenites from Udachnaya kimberlite pipe. Problems of petrography and mineralogy of basic and ultrabasic rock of Eastern Siberia: Irkutsk, p.12-23.

Sobolev, N.V., 1974, Deep-seated inclusions in kimberlites and the problem of the Upper Mantle composition: Novosibirsk, Nauka, 263 p.

Solov'eva, L.V., and Vladimirov, B.M., et al., 1994, Kimberlites and kimberlite-like rocks: the Upper Mantle substance under ancient Platforms: Novosibirsk, Nauka, $256 \mathrm{p}$.

Spetsius, Z.V., and Serenko, V.P., 1990, Composition of continental Upper Mantle and lowermost strata of the crust under Siberian Platform: Moscow, Nauka, 272 p.

Ukhanov, A.V., Pyabchikov, I.D., and Kharkiv, A.D., 1988, Lithospheric Mantle of Yakutian kimberlite province:, Moscow, Nauka, 286 p. 